\title{
An outlook on the role of Finance Regulation under the Fourth Industrial Revolution
}

\author{
Pablo Sanz Bayón \\ Assistant Professor in Commercial Law (PhD) at the Faculty of Law of Comillas Pontifical \\ University (Madrid, Spain) and Member of Everis-Comillas FinTech Legal Observatory \\ Calle Alberto Aguilera, 23 - 28015 Madrid (Spain)
}

\section{Luis Garvía Vega}

Associate Professor in Finance (PhD) at the Faculty of Economics and Business Administration of Comillas Pontifical University (Madrid, Spain) and Member of Everis-Comillas FinTech Legal Observatory. Calle Alberto Aguilera, 23 - 28015 Madrid (Spain)

\begin{abstract}
A new industry called FinTech has emerged within the financial system as of 2008. FinTech promotes a paradigm shift which does not rest as much on products or services being provided as on who provides them, and how are they provided. It is not by chance that such developments, which encompass both new services (i.e. BlockChain, cryptocurrencies or smart contracts) and new players, is taking place in parallel with Internet and mobile devices developments. There is a factor that is common to all such developments: the intensive use of computer technology and the speed and security of information flows. It is somehow ironic that when dealing with financial and technological globalisation, both national lawmakers and the international financial institution framework have so far failed to regulate emerging technologies and commercial issues. The goal of this paper is to provide a reflection on the new digital technologies that are changing the financial system, and to critically examine any feasible approaches to regulatory policies that are able to comprehend and supervise such developments.
\end{abstract}

Keywords: Financial Regulation, Fourth Industrial Revolution, FinTech, RegTech, Financial Markets, Electronic Finance, BlockChain

\section{INTRODUCTION}

We are facing a new paradigm, according to some scholars, the Fourth Industrial Revolution ${ }^{1}$. This revolution, unlike the previous three, involves not only the means of production, but also the information management ${ }^{2}$. One of its consequences is the emergence of a new market ecosystem where the new source of power lies in the access, control and availability of data. As we address below herein, part of the response to the international financial crisis of 2008 has involved a series of measures promoting the concentration and centralization of power within the system, both at organizational and regulatory levels, with the initial goal of correcting market failures and of preventing systemic risks ${ }^{3}$.

\footnotetext{
${ }^{1}$ Bloem, J., Van Doorn, M., et al. (2014). The Fourth Industrial Revolution. Sogeti VINT; and Schwab, K. (2017). The Fourth Industrial Revolution, New York and The Fourth Industrial Revolution: what it means, how to respond. Foreign Affairs. https://www.foreignaffairs.com/articles/2015-12-12/fourth-industrial-revolution 2 Floridi, L. (2010). Information: A Very Short Introduction, Oxford University Press.

${ }^{3}$ McDonnell, D. and Valbruzzi, M. (2014). Defining and classifying technocrat-led and technocratic governments. European Journal of Political Research, Vol. 53, № 4, pp. 654-671.
} 
In line with the process of transformation happened in the traditional power structures, thanks to the new digital ecosystem, most groups and organizations in the most developed areas of the world can reach an inexhaustible source of information, which allows them to get a degree of autonomy never before seen in history. Access to and obtaining information is no longer a problem, although, ironically, that has been taken over by another new problem, which is to be able to properly manage and analysis data against such a huge amount of information available. Such dynamism acts as decentralizing driving force regarding the distribution of social power.

Under the influence of those two opposing trends, i.e., a centralizing trend that involves international organisations which foster and endorse centralization, and decentralizing, which rests on the Internet and on information technologies, FinTech industry appears and transforms the financial market ${ }^{4}$. For example, BlockChain allows building a "distributedledger" network based on cybersecurity which in fact bypasses many institutions and legal mechanisms with which traditional economy is still working and that were hitherto monopolised by central authorities, registries, notaries or certifying public officers and other intermediaries ${ }^{5}$.

This paper intends to focus critically on the regulation of such developments. For this purpose, we shall firstly propose a deductive approach that, relying on the major finance theories, intends to bring in a conceptual framework which enables to understand and to define the new role of Law. Later, and relying upon this conceptual framework and analysing some key elements of FinTech industry developments, we can infer the main challenges that must addressed by the Law. In this regard, this paper intends to contribute to legal policy trends on new digital technologies in finance.

\section{FINANCE AND INFORMATION UNDER THE FOURTH INDUSTRIAL REVOLUTION \\ An Initial Approach}

Information is of key importance both for finance and for the process of spreading technological innovation. If the speed of information flow increases, financial markets tend to adapt. A faster dissemination of technological innovation, furthermore, in a global environment, has as a consequence that the processes of dissemination and assimilation of technology which took decades in the Twentieth Century now take months or even days.

The consequences described in the foregoing paragraph take place normally on their own from the emergence of Internet to 2008, as an indicative and symbolic moment, which coincides with the outbreak of the international financial crisis. During this period, financial markets, although operatively adapted (Internet-based banking, virtual platforms), did not undergo significant structural changes. In fact, the role of financial institutions, international bodies, financial supervisors, financial products and market performance did barely change during that time. In that same period, we have witnessed the impact that faster dissemination of

\footnotetext{
${ }^{4}$ Dapp, TH., Slomka, L., et al. (2014). Fintech-The digital (r)evolution in the financial sector. Deutsche Bank Research.

https://www.deutschebank.nl/nl/docs/Fintech-The_digital_revolution_in_the_financial_sector.pdf 5 Catalini, C. (2017). How BlockChain Technology Will Impact the Digital Economy. Oxford Law Faculty Blog, April 2017. https://www.law.ox.ac.uk/business-law-blog/blog/2017/04/how-blockchain-technology-will-impact-digitaleconomy
} 
technological innovation has had on our society, changing most practices, and growing rich those entrepreneurs able to manage efficiently technology and information.

Technological innovation is gradually converging with the financial sector, not just in an operational way, but bringing in a structural change in the way to understand it. Although it is a gradual process, without a specific start date or moment, for didactic purpose and following certain scholars, we believe that the impact of this trend started to gain momentum from 2008, being FinTech the most common denomination thereof ${ }^{6}$. It is therefore necessary to carry out a critical examination of the new technological developments that are changing the financial system in order to analyse first the impact and the consequences of the increase of data processing speed in the financial markets, regardless of FinTech phenomenon. That shall represent the conceptual framework of this paper and shall retrospectively link information with finance, highlighting the most significant aspects of such link so as to build on the subsequent development of the relevant legislative policies.

\section{The Traditional Response Of Financial Market To Technological Revolution}

The primary role of financial markets is the efficient distribution of capital resources. The level of efficiency of a particular market shall be directly dependent on the ability of the prices of assets exchanged on that market to reflect the information available at any time. Such concept was already enunciated by Professor Eugene Fama in 1969 -probably, the most-quoted paper in the history of international finance- known as Efficient-Market Hypothesis (EMH) ${ }^{7}$. According to this theoretical approach, in the limit a market is efficient if all the players acting within it have the same information. If that happens, no player would be able to gain advantage from the information obtained, or to predict future developments of prices of an asset from the information available.

On this basis, scholars have discussed over the years on market efficiency and certain foundations for different models of financial instruments valuation methods. If a market is efficient, one direct conclusion of EMH is the absence of arbitrage ${ }^{8}$. Thus, in case of inefficiency, that is to say, a possibility of a risk-free profit situation, that market player who detected such inefficiency would have an incentive to remove such inefficiency, thus obtaining a gain and, at the same time, helping the relevant market to be more efficient. Such dynamism caused by arbitrage allows leaving behind the question concerning the efficiency of markets and posing next question: Do markets tend to efficiency? The answer to such question being less controversial. The EMH, in the same way as any other model, is an imperfect approach to reality but has evidenced a great deal of consistency in the way it understands the ability of financial markets to adapt quickly when the information flows and its transmission increases or change. In this sense, a market player who is able to have the faster access to new

\footnotetext{
${ }^{6}$ Arner, D.W., Barberis, J. and Buckley, R.P. (2016). Fintech, RegTech and the Reconceptualization of Financial Regulation. Northwestern Journal of International Law and Business, № 37, pp. 371-414; Arner, D. W., Barberis, J. and Buckley, R. P. (2015). The Evolution of Fintech: A New Post-Crisis Paradigm?. University of Hong Kong Faculty of Law Research Paper No. 2015/047; Arner, D.W, Barberis, J. and Buckley, R.P. (2016). The evolution of Fintech: a new post-crisis paradigm? University of New South Wales Law Research Series, № 62 and Arner, D.W., Barberis, J. et al. (2016). From Fintech to TechFin: The Regulatory Challenges of Data-Driven Finance. European Banking Institute Working Paper Series, № 6.

${ }^{7}$ Fama, E. F. (1969). Efficient Capital Markets: A Review of Theory and Empirical Work. The Journal of Finance, Vol. 25, № 2 (Papers and Proceedings of the Twenty-Eighth Annual Meeting of the American Finance Association, New York. December, 28-30, 1969 (May, 1970), pp. 383-417).

8 Jarrow, R. A. and Larsson, M. (2012). The meaning of market efficiency. Mathematical Finance, Vol. 22, № 1, pp. $1-30$.
} 
information shall have a competitive advantage over competitors, given that he will be able to use those arbitrage opportunities associated to such information ${ }^{9}$.

The role of supervisory bodies according to the EMH is as well closely related to information, in the sense that they are entrusted with the duty of monitoring the truthfulness and transparency of information. Considering the foregoing, increased speed of transmission of information in the financial markets should theoretically get them closer to efficiency. While it is true that the use of technology provides its holder or user to a competitive advantage -which arises a certain tendency to concentration and monopoly-, the EMH was not able on its own neither to prevent not to explain the international financial crisis of 2008, in the same way that it would not have been able to foresee the Wall Street Crash of 1929, not least because it is not a theory that its ultimate goal is to foresee future events.

It is also necessary to point out some significant factors which lead to the financial crisis of 2008. Mainly, we can mention two of them such as truthfulness of the information associated to the increasing complexity of securitised products traded during the period 2004-2008; and the irregularities of some operators such as the credit rating agencies. Against this background, the EMH basically states that if information related to financial assets traded on a particular market is incorrect, when such incorrectness becomes public, markets shall as soon as possible correct the price of assets traded on markets, and so it happened.

\section{Crisis And Collapse Of The Traditional Model}

From its very beginning, there were numerous academics who challenged the EMH. While some directly argued that markets were not efficient, some other gathered a series of empiric anomalies of different nature ${ }^{10}$. Shiller (2003) argued that in 1980 the financial system was already excessively volatile; something that EMH had not been able to explain. Such circumstance, together with the significant number of anomalies in the EMH, fuelled during the 1990s the emergence of different models that included psychological elements associated with investors' behaviour. In apparent opposition to the EMH, the theory known as Behavioural Finance was developed ${ }^{11}$.

It is worth noting that, originally, most of Behavioural Finance's theory was developed directly challenging the EMH. Such challenges were later reflected in the adoption of new regulation policies, so that the policymakers, in the years following the outbreak of the 2008 financial crisis, were at times acting under the premise that most of the previous regulation was not valid anymore. Such approach, far from being helpful, somehow further aggravated the impact of the crisis. From 2008, and in addition to the emergence of new problems associated with FinTech industry, the same old problems, such as so-called flash crashes and news speculative bubbles, began to appear, only that in a faster way ${ }^{12}$.

\footnotetext{
${ }^{9}$ Fama, E. F. (1998). Market efficiency, long-term returns, and behavioral finance. The Journal of Financial Economics, Vol. 49, № 3, pp. 283-306.

10 Malkiel offers a comprehensive analysis on this process. See Malkiel, B.G. (2003). The Efficient Market Hypothesis and Its Critics. Journal of Economic Perspectives, Vol. 17, №1, pp 59-82.

${ }^{11}$ Shiller, R, J. (2003). From Efficient Markets Theory to Behavioral Finance. Journal of Economic Perspectives. Vol. 17 , № 1, pp. 83-104.

12 Kirilenko, A., Kyle, A.S. et al. (2017). The Flash Crash: High-Frequency Trading in an Electronic Market. Journal of Finance, Vol. 72, Issue 3, pp. 967-998.
} 
Therefore, the Behavioural Finance's theory opens a multidisciplinary way where, even if there is not a unifying model, there is indeed an explanation for specific effects and behaviours such as the financial crisis of 2008 and most part of current legal solution to it. Two of the main tools reviewed by this theory are, on one hand, the heuristic methods or bias in making decisions and, on the other, the small rewards theory, so-called nudges. These tools, which originally allowed to explain individuals' behaviours from an economic point of view, may be useful from a regulatory point of view given that, at the end of the day, legislation is also aimed at triggering and rewarding certain particular behaviours and avoiding, prohibiting or discouraging others.

\section{Economic Recovery And Reconciliation With The Traditional Model}

As academic work has evolved, and as time has passed by after the financial crisis of 2008, a certain consensus has been reached, so that the EMH, far from being viewed as contradictory to the Behavioural Finance's theory, can actually be viewed as complementary. The EMH is by definition a simple theory which relates available information in the market to assets price formation. It is of no value in foreseeing potential crisis, it is neither able to identify speculative bubbles, and it is not associated with the failure of large financial institutions ${ }^{13}$. In this regard, Shiller (2014) argues that the EMH must be viewed as a goal or a market tendency instead of as a proven fact 14 .

The financial system is complex and involves at any time countless players whose behaviour can sometimes be described as rational, but which some other times may be influenced by psychological reactions that do not follow specific logic or rational patterns. Moreover, to describe certain human behaviours as rational within a complex system entails associated risks, particularly when the rationality of the behaviour is manifest in mathematical algorithms or standardized formulations widely accepted. If every rational investor made at the same time the same mistake when applying a formula, the outcome might be a disaster, catalysed and magnified in this case due to increased speed in the transmission of information.

Taking into account all of the above, the way in which the Fourth Industrial Revolution has first changed finance can be understood by combining the EMH (emergence FinTech industry and BlockChain technology to counter inefficiencies appearing in the market) and the need to set methods to prevent irrational conducts in the financial system. Such duality (rationalityirrationality), combined with technology and greediness (which is intrinsic to human beings), has contributed to increase the number of transactions, to create new and more complex financial products by means of algorithms, and to materialize systemic risks increasingly often and, under certain circumstances, with a greater impact ${ }^{15}$.

\section{REGULATORY IMPACT OF INTERNATIONAL FINANCIAL CRISIS OF 2008}

As we are examining, the influence of the present international financial crisis has had a special impact on the development of the subsequent legal policy on financial markets. In the first phase, up to 2008, the impact of technology on the financial system was profound from a quantitative point of view, but not in qualitative terms. Since the fall of Lehman, however, there

13 Ball, R. (2009). The Global Financial Crisis and the Efficient Market Hypothesis: What Have We Learned? Journal of Applied Corporate Finance, № 21, 2009, pp. 8-16.

14 Shiller, R. J. (2014). Speculative Asset Prices. The American Economic Review, Vol. 104, Issue 6, pp. $1486-1517$.

15 See footnote № 11 . 
have been significant structural and legislative changes, in parallel with the birth of the FinTech industry ${ }^{16}$.

Before 2008, money as a means of payment, deposit of value and unit of account, was not affected by the Fourth Industrial Revolution. Neither the form of contracting in the system was modified nor the structure of the markets. However, the role of legislators, supervisors or financial intermediaries remained unchanged. After 2008, FinTech is practically affecting all the financial institutions, in parallel with regulatory and structural changes. In this sense, the EMH allows to explain the appearance of the FinTech industry. The main technological innovation of this industry, BlockChain, means to take the postulates of the EMH to its maximum expression because it allows that with the boom of the FinTech industry and its digital tool (Distributed-Ledgers and asymmetric cryptography) ensure, in fact, that all market players in a network have, at the technical level, the same degree of information, and can access and verify computationally all the transactions of such network ${ }^{17}$. In this way, all the nodes of the network, having the same information in real time, make BlockChain work in practice as a registry or public accounting (certainly with its own limitations, but allowing technically the market players obtain and participate in all available information and with maximum security and reliability) ${ }^{18}$.

The economic consequenc of this phenomenon is transcendental. Market players can technically and potentially access the same level of information and with the guarantee of maximum security. Obviously, this situation poses a great challenge to the entire legal and institutional framework, as well as to the leading players in the financial system (big banks). All of them could be surpassed by the new players of the FinTech industry that are leading the development and implementation of first BlockChain systems.

In addition, this new technological revolution questions the role traditionally assigned to legislators and supervisors. Under the pre-FinTech industry paradigm, the EMH conditioned the task of legislators and supervisors. In fact, according to the EMH, legislation and supervision of the financial system should ensure the efficiency of the market. The object and purpose of financial regulation was to provide legal certainty and make the market more efficient. This aim was achieved through a plurality and heterogeneity of measures, both at the institutional and legislative levels: transfer of sovereignty (in the Eurozone, State-members monetary policies ceded to the European Central Bank) ${ }^{19}$, compliance with legislative policy recommendations (IMF, WB, OECD, WTO) and the influence of some international meetings (World Economic Forum) ${ }^{20}$. Not only the regulations promulgated under these schemes were the only instruments to react to the market failures and systemic risks of the global financial system. This explains to a large extent the boom experienced by Corporate Governance, Corporate Social Responsibility and Legal Compliance around the business world in the last decade $^{21}$.

\footnotetext{
16 Altenhain, T. and Heinemann, C. (2017). Fintech Hypes, but Wealthy Internet Savvy Investors Prefer to Stay Hybrid. Digital Marketplaces Unleashed, pp. 343-357.

17 UK Government Chief Scientific Adviser (2016), Distributed Ledger Technology: beyond BlockChain.

18 Tapscott, D. and Tapscott, A. (2016). The impact of BlockChain goes beyond Financial Services. Harvard Business Review, May.

${ }^{19}$ European Banking Authority (2014). EBA Opinion on virtual currencies. EBA/Op/2014/08.

20 World Economic Forum (2016). The role of Financial System in society: understanding the impact of technology-enabled innovation on financial stability.

${ }^{21}$ Elsinger, H., Fessler, P., Feyrer, J., et al. (2018). Digitalization in financial services and household finance: fintech, financial literacy and financial stability. Financial Stability Report.
} 
However, BlockChain, as the technological base of the emergent financial market, reaffirms the model proposed by the EMH, at a technical level. In BlockChain there is no central or regulatory authority or supervisor. The information of transactions is generated and flows without intermediaries but including technological security that makes impossible to alter or hack the data deployed on the network. At the same time, BlockChain is a technology that works as a registry or public accounting, with the security and reliability of the data and transactions contained therein. However, despite these facts, the intervention of regulators and supervisors will be irreplaceable. The access and control of the authentication of the identity and capacity of the players and other operators who access and participate in a BlockChain platform will be always necessary in order to avoid fraud and damages ${ }^{22}$.

Data Science, under this conceptual framework, also contributes to greater market efficiency, especially when big data and data mining are focused on business analytics. In this sense, as the EMH, the market to be efficient must have a continuous, current, public and secure supply of information. For this reason, BlockChain, through the booming FinTech industry (in combination with Data Science), is on track to meet this goal in the short term. But this does not imply that in practice some of the market players can influence more than others in fixing prices, distort competition, violate rights of others, and have more and better information to decide their transactions. For this reason, lawmakers should act to ensure that the most innovative players detect inefficiencies and cover them with new products and services, but by anticipating and sanctioning unfair and harmful behaviors for the public interest. Innovations, in this sense, would act as "patches" of the economic system and move the market towards a trend of efficiency within its natural and irresolvable imperfection, which is intrinsic to all human reality.

\section{EMERGENCE OF THE FINTECH INDUSTRY: THE NECESSARY ARRIVAL OF REGTECH}

As we have already pointed out, legislators and supervisors have been responding to the last international financial crisis with mechanisms that have tried to solve old problems that today new technologies are solving. However, at the same time, because of the institutional architecture of legislative bodies and international organizations, they are not being able to respond effectively to the challenges that these new technologies are generating ${ }^{23}$. In this respect, legal modernization must involve not only legislators but also all legal operators, supervisory bodies, central banks, courts and other administrative bodies, and in general, all those who register or certify transactions on the market (property and commercial registries and notaries), as well as other operators acting as intermediaries (clearing houses and banks).

These players are primarily affected by the disruption that is being caused by the FinTech industry and BlockChain's decentralization applications (smart contracts 24 and cryptocurrencies ${ }^{25}$ ). They should also be the most aware and sensitive about the opportunities and threats that arise for themselves and that will force them to reconfigure soon in order to adapt to the changes. Otherwise, if they do not, or do not promptly promote regulatory changes, they will strain the market players that depend on them, damaging business competitiveness. That is why the new legal policy we call RegTech is crucial for the effective

\footnotetext{
22 World Economic Forum (2016). The future of Financial Infraestructure: an ambitious look at how BlockChain can reshape financial services.

${ }^{23}$ Buchak, G. et al. (2018). Fintech, regulatory arbitrage, and the rise of shadow banks. Columbia Business School Research Paper No. 17-39.

24 Green, S. (2016). Smart Contracts, Oxford Law Faculty Blog

https://www.law.ox.ac.uk/business-law-blog/blog/2017/03/smart-contracts

25 Olnes, S. (2015). Beyond Bitcoin - Public Sector Innovation Using the Bitcoin BlockChain Technology. Western Norway Research Institute.
} 
incorporation of new technologies in the financial system, since the legal framework of these technological phenomena will create incentives or disincentives to the upcoming investments. For this reason, legal policies should take into account that the FinTech industry can reduce transaction costs in the financial market.

RegTech has therefore to be aimed at making financial regulation an efficient instrument to prevent and solve market failures in a technocratic and global economy presided over by the control and analysis of information flows, which have become the main sources of power and social development. The new legal policy must therefore ensure that the regulation does not hinder world trade and business through innovative technologies, removing archaic legal rules, while avoiding the creation of equally inefficient substitute rules.

Therefore, if the market is increasingly virtual through the rise of e-commerce (including in the near future smart contracts and artificial intelligence applications) and money is also digitized in this process (digital currencies, electronic money, new payment services), the legal system should not to stay behind these new technical realities with economic applications, and in turn must be technified ${ }^{26}$. That is, legislators and policy-makers should design new institutions and legal categories, but also regulate mechanisms and control systems to ensure legal certainty for market players and thereby prevent their failures and illegal acts and be able to repress them more effectively. That is the main challenge facing the Law under the Fourth Industrial Revolution.

\section{EMERGING LEGAL CHALLENGES IN FINANCIAL REGULATION}

The great challenge of Law is to regulate a bundle of increasingly complex phenomena within the digital economy whose main asset is the information and speed, security and volume for its spread and analysis. The leading companies of the Fourth Industrial Revolution begin to have specific legal needs that are determined by their particularities and idiosyncrasies: they are multinationals of different sizes, operate in multiple sectors and work on the cyberspace. These new players in the digital economy bring legal challenges that need to be addressed from a regulatory point of view in different areas ${ }^{27}$.

In effect, the FinTech industry is not correctly regulated from the different disciplines of the Law. From the point of view of commercial law, urgent regulatory proposals arise, both in competition law, transparency, consumer law and financial regulation. As for competition law, the existence of technological and banking giants that are absorbing the start-ups of the FinTech industry should draw the attention of policy-makers. Financial regulation should take criteria not only based on the size or target market of the company that could be monopolistic or form oligopolies, but a criterion that has not yet been developed: the need for more data from competitors to increase services of that company or maximize the benefits of its current services. In this regard, lawmakers should pay attention to M\&A operations ${ }^{28}$.

The foregoing question leads to the transparency and disclosure of information obtained through data mining. While business secrets need to be protected, it is no less true that large

\footnotetext{
26 Raskin, M. (2017). The Law and Legality of Smart Contracts. Georgetown Law Technology Review, p. 305.

27 Likewise, RegTech must be accompanied by LegalTech, so that lawyers transform their way of working through innovative technologies and can understand the new needs, situations and problems of their clients.

${ }^{28}$ World Economic Forum (2015). The Future of Fintech: A Paradigm Shift in Small Business Finance. See also Ma, W., Oumet, P. and Simintzi, E. (2016). Mergers and Acquisitions, Technological Change and Inequality. EGCI Finance Working Paper, № 485/2016.
} 
financial and technological corporations must be more transparent in terms of generating benefits through the collection of data and their weight in books. With this transparency (in addition to greater competition), the financial market would obtain a way of contrasting comparable information between companies with the same business model (financial technology), as at present we can compare books of big industrial companies operating in the same sector (for example, two airlines, or two construction companies) because they follow the same accounting international standards.

With regard to financial regulation and the efficiency of capital markets, the new policy must assume that investors get more information about FinTech activities and business plans in the digital economy, as BlockChain. When the market obtains this disseminated information, and it can be circulated and interpreted effectively, capital markets will be more efficient in the transactions that are carried out based on the disclosed public information, as it is stated under the EMH. In this way, the FinTech industry, parallel to Data Science, will not be simply based (as it is currently) on predictions or perspectives on iterations of business models, that is, on predictive analytics about the behavior of the financial market players and the evolution of technology, without concrete, truthful and tangible information. For this reason, a specific regulation is needed in order to require FinTech companies to disclosure information on the generation of cash flows and any other business actions in the financial market and the impact of them on its books, customers and market.

Although the FinTech industry is young and its economy is still using valuation methods according to the venture capital world, given the systematic risk that they can potentially generate over the entire financial market, it would be advisable for the legislators to establish basic criteria, so that the market could disseminate information more efficiently, avoiding potential bubbles and price manipulation. Likewise, an international change in accounting law should be encouraged with the aim of considering data as an asset, with its own depreciation rules and with its differentiated and specific treatment. This measure would be decisive for the evaluation of the FinTech industry. This would mean that the valuation of these financial technology companies would not only be based on profits or turnover, or in the evolution of their cash flows. Through specific legal rules these elements would be related to the technological assets of the company. This would allow to offer a more homogenous valuation and accounting scheme that now does not exist, and finally, this would enforce the reliability of the information in the market.

The difficulty lies in the fact that the FinTech industry operates with technology and information whose value is estimated by the market although it lacks a regulated and comparative accounting method to determine the true and fair view, since many technologies and data may not appear in the books as an asset. For this reason, the way in which the technology is valued, and the data is recorded as an asset in books should be standardized for the benefit of the all market players.

Finally, it should be noted that tax law is the only legal discipline that has come to the new realities of the digital economy in an effective and direct way. The OECD BEPS (Base Erosion and Profit Sharing) project has led to recommendations that have already been developed in the European Union ${ }^{29}$. The aim is that the value of the data and the services digitization do not result in a detriment in the tax revenues of the countries.

${ }^{29}$ Pelkmans J. and Renda, A. (2014). Does EU regulation hinder or stimulate innovation? CEPS Special Report, № 96. 
In any case, all legal disciplines must be coordinated so that regulation is optimal. This aim requires an interdisciplinary will by legislators and international organizations. The regulation of financial technology must be geared towards the wealth creation, a more efficient and equitable market, so that innovations contribute to economic growth. The risk of a late or defective RegTech will be the formation of a pathological FinTech industry, with the potential to destabilize financial markets worldwide through problems and conflicts of concentration and opacity, increasing the potential for bubbles and market failures that infect other sectors, harm consumers and national economies. Behind the veil of the FinTech industry, there must be an economic model that is sustainable over time and controlled in order to support the growth and general advantages offered by the Fourth Industrial Revolution. Now, lawmakers must respond to the regulatory needs of the FinTech industry and the financial market in order to avoid past mistakes and prevent future risks. The FinTech industry is the present and future of finance, so the new legal and institutional framework should be clarified as soon as possible.

\section{CONCLUSIONS AND LEGISLATIVE POLICY RECOMMENDATIONS}

Information is the "raw material" of the Fourth Industrial Revolution. The way it can be managed is being deeply transformed by the new cybernetic tools and the cryptographic ecosystems. Such digital technologies continue to revolutionize the processing of information and its impact on the financial system under a two-staged process: first, a quantitative change (amount of information being transmitted, Big Data), with computerised processes and faster system response speed; and second, a qualitative change (use of information and transformation into knowledge) ${ }^{30}$. In this stage, there is not only an increase in the information transmission speed, also, innovation entails changes in the market structure with the emergence of a new specialized industry (FinTech).

The development of these information technologies is paramount to understand the emergence of FinTech industry that is changing the market through BlockChain (cryptocurrencies and smart contracts applications) by enforcing amendments to the institutional and legislative framework set before and after the international financial crisis of 2008, an institutional and legislative framework unaccustomed to dealing with the complexity paradigm enhanced by the new information and communication technologies applied to the financial system ${ }^{31}$.

In this regard, FinTech is key to understand the EMH general validity and its ability to explain today's world economic context. Market tends to efficiency and, precisely, the emergence of BlockChain provides some progress in this respect by technically decentralizing the financial system given that it eliminates transaction costs while preserving the security and reliability of transactions. This is due to technology sophistication based on computing, encryption and networks.

In parallel to the foregoing, this new scenario under FinTech industry and the emergence of multiple products and services at BlockChain does not entail that risks and failures of the financial market will disappear. According to the Behavioural Finance theories and their heuristic methods, the inescapable presence of human mind in investment decisions, despite process automation, conveys the need of foresee the consequences of both human irrationality and information management in complex environments.

\footnotetext{
${ }^{30}$ Floridi, L. (2014). The Fourth Revolution: How the Infosphere is Reshaping Human Reality, Oxford University Press.

${ }^{31}$ Arthur, W.B. (2015). Complexity and the Economy, Oxford Economic Press.
} 
These new circumstances are driving the emergence of an early RegTech trend capable of accommodate companies and institutions to the new technological changes that are overturning global economy. This new scenario highlights the substantial importance of Law as guarantor of legal certainty for all the players in the financial market, by providing transparency, setting legal mechanisms that play a part in the effective reduction of transaction costs, restriction of information asymmetries, consumer protection for electronic financial products and services and look after public interests at stake. Therefore, technological revolution on finance (FinTech) must give way to a legal revolution (RegTech) which enables Law to modernize and to provide ideal solutions to new scenarios characterized by database systems and decentralizing electronic platforms which do not need central authorities or public notaries or registries and agents as we know them.

Legal certainty as traditionally perceived (i.e. by means of central authorities or systems, registries, public attestations or authentications, and so on) is revamping via cybersecurity (encryption). Hence, we are faced with a paradox: on the one hand, the emergence of new technological advances makes legal certainty a concept which needs to be modernized; while on the other hand, such new digital technology is now capable of providing certainty, although is not regulated at this moment. Present cryptography-based cybersecurity systems enable to apply many uses and functionalities that are changing the traditional theories on money and contracts. Thus, the conflict between old centralizing forces (both previous and subsequent to the international financial crisis of 2008) and new decentralizing forces (FinTech-BlockChain) shall give rise to a complete overhaul of the market about which Law cannot remain unaware. Governments and international organizations might lose their supervisory capacity to face the digital economy turmoil. There is also an ambivalent tendency towards delegation or externalization of their watchdog role (through Compliance mechanisms, Corporate Governance, and Corporate Social Responsibility). Regulation is being decentralized and introduced into the DNA of companies. This supposedly should contribute to an improved business administration in general and, particularly, to better risk management.

Another paradox is that while the banking sector in the world's leading economies continue to be hyperregulated and promoting concentration and mergers of entities as a legal solution to this liquidity and solvency crisis, at the same time we witness the emergence of a powerful decentralizing technology (BlockChain) and of new players (FinTech industry), and a new concept of money and trading (cryptocurrencies, smart contracts) bound to lead an overhaul in the financial system. The success of the Fourth Industrial Revolution shall depend on how lawmakers understand all these new digital technologies and trends.

\section{References}

Altenhain, T. and Heinemann, C. (2017). Fintech Hypes, but Wealthy Internet Savvy Investors Prefer to Stay Hybrid. Digital Marketplaces Unleashed, pp. 343-357.

Arner, D. W., Barberis, J. and Buckley, R. P. (2015). The Evolution of Fintech: A New Post-Crisis Paradigm?. University of Hong Kong Faculty of Law Research Paper No. 2015/047.

Arner, D.W, Barberis, J. and Buckley, R.P. (2016). The evolution of Fintech: a new post-crisis paradigm? University of New South Wales Law Research Series, № 62.

Arner, D.W., Barberis, J. and Buckley, R.P. (2016). Fintech, RegTech and the Reconceptualization of Financial Regulation. Northwestern Journal of International Law and Business, № 37, pp. 371-414.

Arner, D.W., Barberis, J. et al. (2016). From Fintech to TechFin: The Regulatory Challenges of Data-Driven Finance. European Banking Institute Working Paper Series, № 6.

Arthur, W.B. (2015). Complexity and the Economy, Oxford Economic Press.

Ball, R. (2009). The Global Financial Crisis and the Efficient Market Hypothesis: What Have We Learned? Journal of Applied Corporate Finance, № 21, 2009, pp. 8-16. 
Bloem, J., Van Doorn, M., et al. (2014). The Fourth Industrial Revolution. Sogeti VINT; and Schwab, K. (2017). The Fourth Industrial Revolution, New York and The Fourth Industrial Revolution: what it means, how to respond. Foreign Affairs. https://www.foreignaffairs.com/articles/2015-12-12/fourth-industrial-revolution

Buchak, G. et al. (2018). Fintech, regulatory arbitrage, and the rise of shadow banks. Columbia Business School Research Paper No. 17-39.

Catalini, C. (2017). How BlockChain Technology Will Impact the Digital Economy. Oxford Law Faculty Blog, April 2017. https://www.law.ox.ac.uk/business-law-blog/blog/2017/04/how-blockchain-technology-will-impactdigital-economy

Dapp, TH., Slomka, L., et al. (2014). Fintech-The digital (r)evolution in the financial sector. Deutsche Bank Research.https://www.deutschebank.nl/nl/docs/FintechThe_digital_revolution_in_the_financial_sector.pdf

Elsinger, H., Fessler, P., Feyrer, J., et al. (2018). Digitalization in financial services and household finance: fintech, financial literacy and financial stability. Financial Stability Report.

European Banking Authority (2014). EBA Opinion on virtual currencies. EBA/Op/2014/08.

Fama, E. F. (1969). Efficient Capital Markets: A Review of Theory and Empirical Work. The Journal of Finance, Vol. 25, № 2 (Papers and Proceedings of the Twenty-Eighth Annual Meeting of the American Finance Association, New York. December, 28-30, 1969 (May, 1970), pp. 383-417).

Fama, E. F. (1998). Market efficiency, long-term returns, and behavioral finance. The Journal of Financial Economics, Vol. 49, № 3, pp. 283-306.

Floridi, L. (2010). Information: A Very Short Introduction, Oxford University Press.

Floridi, L. (2014). The Fourth Revolution: How the Infosphere is Reshaping Human Reality, Oxford University Press.

Green, S. (2016). Smart Contracts, Oxford Law Faculty Blog https://www.law.ox.ac.uk/business-law-

blog/blog/2017/03/smart-contracts

Jarrow, R. A. and Larsson, M. (2012). The meaning of market efficiency. Mathematical Finance, Vol. 22, № 1, pp. 130.

Kirilenko, A., Kyle, A.S. et al. (2017). The Flash Crash: High-Frequency Trading in an Electronic Market. Journal of Finance, Vol. 72, Issue 3, pp. 967-998.

Malkiel, B.G. (2003). The Efficient Market Hypothesis and Its Critics. Journal of Economic Perspectives, Vol. 17, №1, pp 59-82.

McDonnell, D. and Valbruzzi, M. (2014). Defining and classifying technocrat-led and technocratic governments. European Journal of Political Research, Vol. 53, № 4, pp. 654-671.

Olnes, S. (2015). Beyond Bitcoin - Public Sector Innovation Using the Bitcoin BlockChain Technology. Western Norway Research Institute.

Pelkmans J. and Renda, A. (2014). Does EU regulation hinder or stimulate innovation? CEPS Special Report, № 96.

Raskin, M. (2017). The Law and Legality of Smart Contracts. Georgetown Law Technology Review, p. 305.

Shiller, R, J. (2003). From Efficient Markets Theory to Behavioral Finance. Journal of Economic Perspectives. Vol. 17, № 1, pp. 83-104.

Shiller, R. J. (2014). Speculative Asset Prices. The American Economic Review, Vol. 104, Issue 6, pp. 1486-1517.

Tapscott, D. and Tapscott, A. (2016). The impact of BlockChain goes beyond Financial Services. Harvard Business Review, May.

UK Government Chief Scientific Adviser (2016), Distributed Ledger Technology: beyond BlockChain.

World Economic Forum (2015). The Future of Fintech: A Paradigm Shift in Small Business Finance. See also Ma, W., Oumet, P. and Simintzi, E. (2016). Mergers and Acquisitions, Technological Change and Inequality. EGCI Finance Working Paper, № 485/2016.

World Economic Forum (2016). The future of Financial Infraestructure: an ambitious look at how BlockChain can reshape financial services.

World Economic Forum (2016). The role of Financial System in society: understanding the impact of technologyenabled innovation on financial stability. 